\title{
ANALISIS SEMIOTIKA PADA KUMPULAN PUISI \\ BANTALKU OMBAK SELIMUTKU AINGIN \\ KARYA D. ZAWAWI IMRON
}

\author{
Ryan Hidayat \\ Universitas Indraprasta PGRI \\ ryan.hidayat@unindra.ac.id
}

Tujuan artikel ini untuk menganalisis kajian semiotika pada kumpulan puisi Bantalku Ombak Selimutku Angin Karya D. Zawawi Imron. Dalam mengapresiasi puisi sering kali menyebabkan kecenderungan pendekatan dalam mengkaji karya sastra. Kecenderungan pertama akan memperhatikan kesadaran dan ketidaksadaran pengarang, serta seluruh lingkungan sosial, politik, dan intelektualnya sebagai penentu makna puisi. Kecenderungan kedua beranggapan bahwa makna puisi yang sesungguhnya merupakan hasil atau akibat dari interaksi antara pembaca dan puisi yang dibaca.

Kata Kunci : Analisis, Semiotika, Puisi

\section{PENDAHULUAN}

Puisi adalah suatu sistem penulisan yang margin kanan dan penggantian barisnya ditentukan secara internal oleh suatu mekanisme yang terdapat dalam baris itu sendiri. Beberapa ahli yang merumuskan pengertian puisi menggunakan berbagai pendekatan Slamet Mulyana (1956) memberi batasan puisi dengan menggunakan pendekatan psikolinguistik, karena puisi merupakan karya seni yang tidak saja berhubungan dengan masalah bahasa tetapi juga berhubungan dengan masalah jiwa.
Dalam mengapresiasi puisi sering kali menyebabkan kecenderungan pendekatan dalam mengkaji karya sastra. Kecenderungan pertama akan memperhatikan kesadaran dan ketidaksadaran pengarang, serta seluruh lingkungan sosial, politik, dan intelektualnya sebagai penentu makna puisi. Kecenderungan kedua beranggapan bahwa makna puisi yang sesungguhnya merupakan hasil atau akibat dari interaksi antara pembaca dan puisi yang dibaca. Jadi, kecenderungan kedua bertentangan dengan kecenderungan yang pertama: apabila yang pertama berpusat pada 
kausalitas atau sebab-musabab kelahiran pisi, maka yang kedua berpusat pada efek puisi.

Salah satu karya sastra yaitu puisi. Salah satu cara untuk memberikan kritik pada puisi adalah melalui pendekatan semiotik. Adapun puisi yang akan penulis kritik adalah kumpulan puisi Bantalku Ombak Selimutku Angin KaryaD. Zawawi Imron.

Semiotik merupakan ilmu yang mengkaji hal-hal yang berkaitan dengan komunikasi. Menurut Eagleton, semiotik atau semiologi berarti ilmu tanda-tanda (sign) secara sistematik. Semiotik menunjukan bidang kajian khusus, yaitu sistem yang secara umum dipandang sebagai tanda, seperti puisi, rambu-rambu lalu lintas dan nyanyian burung.

Ada tiga jenis tanda yaitu ikonik, indeksikal, dan simbolik. Ikonik adalah tanda yang menyerupai obyeknya seperti foto seseorang. Indeksikal adalah tanda yang memiliki hubungan dengan obyeknya, seperti asap dengan api.
Simbolik adalah tanda yang secara abitrer atau konvensional dikaitkan dengan rujukannya. Dengan simbolik sesuatu yang abstrak bisa dijadikan lebih konkrit, dan dengan simbolik dapat pula memberikan kesan yang dalam dan pengalaman yang luas tentang sesuatu keadaan atau hal yang mempunyai sifat bermacam-macam. Simbolik pada dasarnya ialah kiasan, simbolik banyak digunakan dalam pengimajian. Dengan menggunakan katakata tertentu sebagai perlambangan dapat memudahkan pemahaman oleh pembaca mengenai sesuatu keadaan yang abstrak, karena sesuatu yang semula abstrak telah dikonkritkan oleh lambang-lambang yang digunakan.

\section{METODE PENELITIAN}

Metode penelitian yang digunakan adalah penelitian deskripstif kualitatif. Sumber data dalam penelitianberasal dari antologi puisi Bantalku Ombak Selimutku Angin Karya D. Zawawi Imron. Data dalam penelitian ini berasal dariseluruh kata-kata dalam setiap bait serta gaya bahasa yang 
terdapat dalam puisi Bantalku Ombak

Selimutku Angin Karya D. Zawawi Imron.

HASIL DAN PEMBAHASAN

Dalam buku kumpulan puisi

Bantalku Ombak Selimutku Angin Karya

D. Zawawi Imron penulis akan meneliti 5

puisi yang terdapat dalam buku tersebut.

\section{Sejenis Kabar}

Pada malam yang hendak pamitan

Merai menanyakan embun kemarau

Lalu terdengar bisik-bisik angin

Didaun padi

"anak yang hilang dalam kandungan

Akan datang pagi ini menjemput mayat

ibunya

Untuk dikubur diubun bulan"

Sedang bulan sudah tenggelam

Membawa pesan-pesan alam

$$
\text { Di langit }
$$

Di balik awan yang samar-samar

Terlukis sebuah senyuman

Dari susunan puisi diatas mempunyai susunan yang tidak teratur, bait satu berjumlah 4 baris, bait kedua berjumlah 5 baris, bait ke 3 berjumlah 2 baris dan bait ke 4 berjumlah 3 baris.
Puisi ini menggambarkan tentang berita duka. Sang penyair menggambarkan sebuah kabar burung dipagi hari yang berisi tentang seorang anak yang belum pernah bertemu dengan ibunya sejak dilahirkan, dan dia memdapat kabar dipagi hari atas kematian ibunya, kemudian di susul oleh dia ( anak ) yang dikubur kesunyian. Terlihat pada :

Pada malam yang hendak pamitan

Merai menanyakan embun kemarau

Lalu terdengar bisik-bisik angin

Didaun padi

"anak yang hilang dalam kandungan

Akan datang pagi ini menjemput mayat ibunya

Untuk dikubur diubun bulan"

Simbol-simbol :

- Malam yang hendak pamitan

- Hilang dalam kandungan

- Datang pagi ini

- Mayat ibunya

- Di kubur siubun bulan

- Bulan sudah tenggelam

- Awan yang samar-samar

Pesan

Kalau aku datang malam

Sambutlah aku

Dengan buah siwalan muda

Yang putih

Kudamba minum

Seteguk nira 
Yang bening

Yang menetes

Dari matamu

Tak usah engkau bicara

Seteguk nira yang bening

Cukuplah

Buat kubawa pergi

Mungkin

Tak kembali

Dari puisi di atas mempunyai susunan yang teratur bait 3 . Bait 1 terdiri dari 4 baris, bait 2 terdiri dari 5 baris, dan bait 3 terdiri 6 baris.

Apabila puisi ini diartikan maka penyair menggambarkan seseorang memberikan pesan kepada kekasihnya, karena ia akan pergi jauh dan mungkin tidak akan kembali.

Kata-kata "kudamba minum" mengartikan bahwa seseorang yang mendambakan kekasihnya waktu semasa berkasih sayang, karena ia akan pergi. Dambaan itu dapat dilihat dari ungkapan kata "seteguk nira" mengartikan bahwa kasih sayang yang diberikan. Perasaan sayang dilihat ungkapan kata "Yang bening" mengartikan bahwa benar-benar kerasa rasa yang diberikan, benar-benar melekat, lihat pula pada kata "yang menetes" dan "dari matamu" artinya benar-benar merasakan nikmatnya bercinta dan kenangan.

Simbol-simbol :
- Buah siwalan

- Seteguk nira

- Seteguk nira yang bening

Pada puisi "Pesan" ini, karya puisi ini bagus karena sudah menggunakan makna kiasan dan majas, pemilihan kata yang digunakan sudah tepat. Tetapi kekurangan puisi ini pada setiap baitnya itu selalu di penggal, penggalan puisi dan terkesan tidak nyambung. Contoh pada bait pertama

Kalau aku datang malam

Sambutlah aku

Dengan buah siwalan muda Yang putih

Menurut penulis ini kata yang rancu, berbeda bila kita ubah rangkaian katanya.

Kalau aku datang

Malam sambutlah aku

Dengan buah siwalan muda Yang putih

\section{Gadis Kampung Jambangan}

Dalam kumandang saronen pesta kerapan

Kujumpa seorang dara

Dengan agak-agak pada hatinya

Lalu diraihnya bulan yang biru

Pada mata penyair

Aku ingat di sini Madura

Lalu terbayang kesekian kilat celurit

Sehingga kedua hati

Saling menyanyi sendiri-sendiri 
Dari puisi di atas mempunyai susunan yang teratur bait 2 . Bait 1 terdiri dari 5 baris dan bait 2 terdiri dari 4 baris.

Kata-kata "dalam kumandang saronen pesta kerapan" mengartikan bahwa pada saat ada acara pesta kerapan, "kujumpa seorang dara" bertemu dengan seorang wanita, "dengan agak-agak pada hatinya" dengan malu-malu mereka melirik, "lalu diraihnya bulan yang biru" merasakan getaran di hatinya, seolah-olah meraih hatinya, "pada mata penyair" pada kedua insan.

Simbol-simbol :

- Saronen pesta kerapan

- Dara

- Bulan yang biru

- Mata penyair

- Kilat celurit

- Menyanyi sendiri-sendiri

\section{Ibu}

Kalau aku merantau lalu datang musim kemarau

Sumur-sumur kering, daunan pun gugur bersama reranting

Hanya mata air airmatamu, ibu, yang tetap lancar mengalir

Bila aku merantau

Sedap kopyor susumu dan ronta kenakalanku

Di hati ada mayang siwalan memutikkan sari-sari kerinduan
Lantaran hutangku padamu tak kuasa

kubayar

Ibu adalah gua pertapaanku

Dan ibulah yang meletakkan aku di sini

Saat bunga kembang menyerbak bau sayang

Ibu menunjuk ke langit, kemudian ke bumi

Aku mengangguk meskipun kurang mengerti

Bila kasihmu ibarat samudera Sempit lautan teduh

Tempatku mandi, mencuci lumut pada diri Tempatku berlayar, menebar pukat dan melempar sauh

Lokan-lokan, mutiara dan kembang laut semua bagiku

Kalau aku ikut ujian lalu ditanya tentang pahlawan

Namamu, ibu, yang kan kusebut paling dahulu

Lantaran aku tahu

Engkau ibu dan aku anakmu

Bila aku berlayar lalu datang angin sakal Tuhan yang ibu tunjukkan telah kukenal Ibulah itu, bidadari yang berselendang bianglala Sesekali datang padaku Menyuruhku menulis langit biru Dengan sajakku

Jika dilihat dari susunan puisi diatas mempunyai susuna yang teratur bait 1 
berjumlah 3 baris, bait ke 2 berjmlah 4 baris, bait ke 3 berjumlah 5 baris, bait ke 4 berjumlah 9 baris, bait ke 5 berjumlah 6 baris.

Sang penyair menggambarkan kasih sayang seorang anak kepada ibu terlihat pada bait pertama yaitu Kalau aku merantau lalu datang musim kemarau,Sumur-sumur kering, daunan pun gugur bersama reranting, Hanya mata air airmatamu, ibu, yang tetap lancar mengalir.

Yang memiliki arti bahwa saat dia pergi jauh, timbul kesulitan yang datang bertubitubi dan hanyapengorbananmu tetap abadi, dan bait ke 2 yang berisi Bila aku merantau Sedap kopyor susumu dan ronta kenakalanku Di hati ada mayang siwalan memutikkan sari-sari kerinduan lantaran hutangku padamu tak kuasa kubayar, yang diartikan bila aku jauh timbul rasa manjaku dan kekanak- kanakanku, sedang hati merasakan kerinduan, itu semua karena pengabdianmu dan pengorbananmu terlalu berharga, dan bait ketiga Ibu adalah gua pertapaanku, dan ibulah yang meletakkan aku di sini, Saat bunga kembang menyerbak bau sayang, ibu menunjuk ke langit, kemudian ke bumi, aku mengangguk meskipun kurang mengerti, yang bila diartikan ibu adalah rumahku dan ibu adalah orang yang melahirkanku, saat aku tumbuh dewasa ibu menasehatiku, aku berkata ia meskipun aku kurang paham.dan bait selanjutnya Bila kasihmu ibarat samudera Sempit lautan teduh, empatku mandi, mencuci lumut pada diri, tempatku berlayar, menebar pukat dan melempar sauh, lokan-lokan, mutiara dan kembang laut semua bagiku, kalau aku ikut ujian lalu ditanya tentang pahlawan, namamu, ibu, yang kan kusebut paling dahulu, lantaran aku tahu, engkau ibu dan aku anakmu, yang memiliki arti kasih sayang luas dalam tiada ujung, tiada tempat berpijak, untuk menceritakan segala resahku, memberi nasihat-nasihat yang baik, kalau aku ditanya siapa idolaku, aku memjawab ibu adalah idolaku, semua tahu bahwa ibu adalah ibuku.

Simbol-simbol :

- Merantau

- Musim kemarau

- Sumur kering

- Daun gugur

- Reranting

- Air mata

- Sedap kopyor

- Mayang siwalan

- Memutikan

- Gua pertapaan

- Meletakan

- Bunga kembang menyerbak

- Bau sayang

- Samudera

- Sempit lautan teduh 
- Memcuci lumut

- Berlayar

- Menebar pukat

- Melempar sauh

- Lokan-lokan

- Mutiara

- Kembang laut

- Ujian lalu

- Pahlawan

- Berlayar

- Angin sekal

- Bidadari yang berselendang bianglala

- Langit biru

\section{Tamu}

Pohon siwalan melambai kabut

Karena angin tak mungkin memanggil senja dan siang

Dan siang tak seteduh lagu seruling itu

Yang masih hanya ayun kembang buncis

Di penghujung kokok ayam terhamparlah laut

Oi, ada perahu melempar sauh Membongkar muatan bunga-bunga subuh

Dari bait pertama sampai tiga dilukiskan suasana yang hampir gelap sedang angin tak dapat mengembalikan suatu keadaan menjadi terang, di suasana yang redup suara seruling tidak semerdu pada sing hari.
Paragraf kedua menggambarkan suasana pagi hari buta (subuh) terdengar suara kokok ayam yang sekaligus terhampar luas lukisan alam (laut), dan juga terdapat perahu nelayan yang membangunkan bunga-bunga di subuh hari.

Simbol-simbol :

- Pohon siwalan

- Memanggil senja

- Lagu seruling

- Ayun

- Kembang buncis

- Kokok ayam

- Melempar sauh

- Bunga-bunga subuh

\section{Lagu Petani}

Pada tekstur tegalan Sehabis ayun cangkul musim penghujan Ada corak hati menyimpan nyanyian Kini yang dekat adalah pantai Di pantai Yang padanya tak tiba rindu Setangkai seludang Merangkum buliran mayang

Dan mayang

Akan setia

Mengharumkan keringat segar Samapi jauh ke padang mahsyar

Dalam doamu, sahabatku! $\mathrm{Ku}$ lihat kupu-kupu akan hinggap Ke kembang randu. Oh, Tuhanku! 
Pada paragraf pertama menggambarkan suasana pantai yang menyimpan nyanyian seorang petani di kala musim penghujan. Pada paragraf kedua suasana pantai yang sunyi tak ada rasa rindu yang ada hanya setangkai seludang yang mendekap buliran mayang.

Paragraf tiga walaupun padang mahsyar berjarak jauh, mayang berjanji akan tetap setia dan mengharumkan keringat segar. Paragraf ke-empat dalam doa seorang sahabat tergambar kupu-kupu yang indah yang akan hinggap di kembang randu

Simbol:

- Tekstur tegalan

- Ayun cangkul

- Corak hati

- Setangkai seludang

- Buliran mayang

- Keringat segar

- Padang mahsyar

- Kembang randu

\section{Senja}

Jika senja bermandi jingga

Selamat pulang, bocah gembala!

Derap langkah sapimu

Di bentang hatiku

Hidup angin dan napas

Langit dan pandang mata jauh lepas

Teduh jiwa merdeka:

Hati kandang dan sumur batu

Jika dilihat dari susunan puisi diatas mempunyai susunan yang teratur pada bait 1 berjumlah 4 baris, dan bait 2 berjumlah 4 baris

Sang penyair menggambarkan kepulangan sang penggembala dengan derap langkah sapinya,terlihat pada kalimat berikut, Jika senja bermandi jingga, selamat pulang, bocah gembala! Derap langkah sapimu, Di bentang hatiku,

Paragraf selanjutnya berisi tentang kebebasannya dari pekerjaannya penggembala, terlihat pada kalimat berikut, Hidup angin dan napas, Langit dan pandang mata jauh lepas, Teduh jiwa merdeka, Hati kandang dan sumur batu,

Simbol

- $\quad$ Senja bermandi jingga

- Jiwa merdeka

- Hati kadang

- Sumur batu

\section{Padang tak Terjangkau}

Akan datang dari padang

Akan pergi dari padang

Padang di pundak kemarau

Padang di jantung musim penghujan

Ada lagi padang

Jauh dan tak terjangkau

Jika dilihat puisi di atas mempunyai susunan 1 bait. Bait 1 terdari dari 6 baris. Apabila puisi ini diartikan maka penyair menggambarkan manusia yang tidak bisa menjangkau padang yang akan di jangkau. Kata-kata "padang di pundak kemarau" artinya bahwa sejauh mata memandang bahwa padang itu ingin di jangkau, tetapi hanya impian saja. Lihat pada baris berikutnya "padang di jantung musim penghujan" artinya padang itu hanya tinggal kenangan saja, walaupun sudah di musim penantian. "Ada lagi padang", artinya ada lagi padang dalam penantian, 
"jauh dan tak terjangkau" artinya ada lagi padang, tetapi jauh dan sulit untuk terjangkau.

Simbol-simbol :

- Pundak kemarau

- Di jantung musim penghujan

- Terjangkau

\section{Pantai Dinari}

Bulan lelah diatas malam

Tapi panas jahe menjalar didasar hati Mulai ada suara yakin

Dan sesuatu yang akan takluk mendingin

Menyani riak yang dirayap angin

Pada layar yang mulai tergelar

Terkibar hati dari daratan hijau

Hati yang bersolek diatas teluk biru yang

beradu

Oi, dinginnya angin dinari !

Jikapun tegak mewarnai kehidupan

Di bawah bulan yang mulai bendereng

Layar yang kembang menebik pada pantai

- Selamat tinggal!

- Selamat jalan!

\section{8}

Jika dilihat dari susunan puisi diatas mempunyai susunan yang teratur bait 1 berjumlah 4 baris, bait ke 2 berjumlah 5 baris

Puisi ini menggambarkan Perpisahan

Sang penyair menggambarkan sebuah perpisahan dimalam hari terlihat pada Bulan lelah diatas malam, tapi panas jahe menjalar didasar hati, mulai ada suara yakin, dan sesuatu yang akan takluk mendingin, menyani riak yang dirayap angin, Jikapun tegak mewarnai kehidupan, Di bawah bulan yang mulai bendereng, Layar yang kembang menebik pada pantai

- Selamat tinggal!

- Selamat jalan!

Simbol

- Panas jahe

- Suara yakin

- Takluk mendingin

- Menyanyi riak

- Dirayap angin

- Tergelar

- Retakbir hati

- Daratan hijau

- Hati yang bersolak

- Teluk biru

- Beradu

- Angin dinari

- Layar yang kembang

- Menabik pada pantai

\section{Musim Labuh}

Jatuh gerimis musim labuh

Wahai, manis!

Pada wangi tanah siwalan

Ada bau sendu menikam

Kutatap sepi

Paras ladam yang merangkum merah membasah

Hanya seorang petani

Menghayati hakekat sepi

Di kaki bukit

Ada nyanyi pilu bening

Hasrat yang biru memburu wangi ke puncak bukit

Cuaca dingin

Mengabur bersama warna

Rindu yang ungu 


\author{
Gerimis kembali jatuh \\ Di sini, manis! \\ Ada hakekat baru tumbuh \\ Yang kurengkuh
}

Puisi di atas menggambarkan suasana musim labuh yang sepi dan dengan cuaca yang gerimis di kaki bukit di berengi dengan kerinduan dengan cuaca yang dingin dan rasa rindu yang menggebu seorang petani namun walaupun begitu semua terasa manis karena tumbuh lagi bibit labuh yang baru

Simbol-simbol :

- Musim labuh

- Tanah siwalan

- Sendu menikam

- Kaki bukit

- Pilu bening

- Mengabur

- Rindu yang ungu

- Gerimis

- Memburu wangi

- Hakekah

- Kurengkuh

\section{KESIMPULAN}

Penggunaan semiotika dalam kumpulan puisi "Bantalku Ombak Selimutku Angin" karya D. Zawawi Imron ditemukan penggunaannya. Lebih banyak simbol yang ada dalam kumpulan puisi tersebut.

Dari kelima judul puisi yang terdapat dalam kumpuluan puisi "BantalkuOmbakSelimutkuAngin" semuanya menggunakan unsure semiotic berupa symbol warna, puisi tersebut meliputi Senja yang Merah, Di bawahlayar, Di Tengah Hamparan Sawah, dan Pertemuan dengan Pak Dirman.

\section{DAFTAR PUSTAKA}

Fananie, Zainuddin. 2000. Telaah Sastra.

Surakarta: Muhammadiyah University

Press.

Hasanuddin WS. 2002. Membaca dan

Menilai Sajak. Bandung: Angkasa

Moleong, J. Lexy. 2010. Metode

Penelitian Kualitatif. Jakarta: Remaja

Rosda.

Nurgiyantoro, Burhan. 1995. Teori

Pengkajian Fiksi. Gadjah Mada:

University Press.

Pradopo, Rachmat Djoko. 2000.

Pengkajian Puisi. Yogyakarta: FSUGM. 